\title{
FORMULATING AN OPTIMAL DRAINAGE MODEL FOR THE CALABAR AREA USING CARTOGRAPHIC TECHNIQUES
}

\author{
Innocent A. Ugbong ${ }^{1}$, Ivan V. Budagov ${ }^{2}$
}

1 Department of Cadaster and Geo-engineering, Kuban State Technological University, Krasnodar, Russia, e-mail: inno_ugbong@yahoo.com

2 Department of Cadaster and Geo-engineering, Kuban State Technological University, Krasnodar, Russia, e-mail: ivan_budagov@mail.ru

Received: 2015.10 .26

Accepted: 2015.12.09

Published: 2016.01.06

\begin{abstract}
In order to achieve the task of formulating an optimal drainage model for the Calabar area, the Calabar drainage system was studied using some cartographic techniques to analyze its surface run-off and channel characteristics so as to determine how floods are generated. A morphological analysis was done, using detailed contour maps prepared for the study area. The "Blue line" and "contour crenulations" methods were used to recreate the expected run-off channels or drainage networks under natural non-urbanized conditions. A drainage structure with 6 major basins and 73 sub-basins was discovered. Existing storm drains were constructed without regards to this natural structure and so floods were generated.
\end{abstract}

Keywords: drainage basin, contour maps, urban floods, storm water, erosion.

\section{INTRODUCTION}

As far back as 5000 years ago, in the classical days of urban development in the ancient Babylonian Empire, systems of stormwater management had already been in operation. The systems relied on drainage channels that collected stormwaters and wastewaters within the urban space and transported them away for discharge into water bodies [Chocat et al. 2004; Chocat et al. 2007]. Over time, especially in the 19th century, significant changes occurred in engineering practice towards the perfection of this concept; but the key paradigm remained the same: "stormwater and other wastewater should be collected in urban areas and disposed outside of the urban environment as quickly and as completely as possible" [Chocat et al. 2004]. In the course of the last few decades, some compelling factors have dictated changes in the concepts of urban water management; leading to a departure from the age long enduring paradigm [Itam, et al, 2015].

Over the last one hundred years, man's need to protect himself and his possessions from the threat of flood and erosion has remained one of the most important considerations in his water conservation efforts [Shmitt, 1997]. Acknowledging the enormity of this problem, the United Nations Environmental Programme (UNEP) had indicated that many communities in the developing world consider uncontrolled storm-water drainage to be their most urgent problem, as far as the preservation of urban infrastructure is concerned [UNEP, 1991].

In Nigeria, especially in the southern and eastern parts of the country, these problems have been most severe. It was in recognition of the severity and magnitude of these problems that the Federal Government of Nigeria for and on behalf of the states affected (Abia, Akwa Ibom, Imo and Cross River) requested assistance from the United Nations Development Programme (UNDP) under its Fourth Country Programme for Environmental and Natural Resources Management to tackle the problem.

Against this background, the UNDP in 1995 commissioned five consultants to carry out baseline studies and design a programme to 
combat erosion, landslide, flooding and other forms of degradation in the affected states [Effiong-Fuller, 1998].

These drainage problems have not only posed a threat, but have actually caused serious damage to lives and property in Calabar urban for several years now. At several areas within the city, the entire streets were converted into yawning gullies. In a hydro-physical study of the Calabar area about 25 flood sites and 55 erosion and landslide sites were identified at the peak of the rainy season, in July [Ugbong, 2001]. By December of the same year, this number increased to 35 flood and 80 erosion/landslide sites.

Studies of urban flooding and erosion have identified their causes to include: the nature of slopes or gradient of the given area, inadequate drainage channels, impervious urban surfaces, heavy rainfall and clogging of drains by refuse dumping [Harbor, 1994; Shake, 1970]. But the critical factor of run-off and how it is organized into a network of flow channels has been largely ignored in these studies. Yet, these networks have been accepted as the most useful unit within which to study the problems of water supply, erosion, flooding and pollution [Dobson, 2006; McCullagh, 1978].

Unfortunately, for most urban centres, such basic information relating to the natural drainage characteristics of the area is lacking. In the Calabar area for instance, run-off channels may have been designed without these basic data, and may have relied on empirically-derived criteria (Adeleye, 1990). This is because the channels have only helped to alter the points of incidence of floods, while solving the problems only in a few areas [Chima and Ugbong, 2009; Itam, et al, 2015]. Where the drainage channels are covered up, this has led to constriction, and during high floods, water backs up and increase flooding upstream. Sometimes water simply overflows the covered segments. Examples of these flood points include the Goldie/Target road segment and Cross River University of Technology (CRUTECH) staff quarters.

There were also other problems of wrong alignment of the channels against the natural flows, leading to the loss of concrete linings to erosion, and large-scale gulling on channels not properly aligned. The problem was further compounded by indiscriminate refuse disposal into the drains and clogging of channels by sediments, as well as the inability of channels to flow by gravity.
This paper investigated these problems by recreating the natural drainage networks within the Calabar area, using the cartographic technique of contouring. The approach here considered the entire study area as a unit drainage basin, with numerous storm drains and ephemeral run-off channels as stream networks.

The assumption was that run-off in any given area responds to the same mechanistic laws as major river channels. And of course, as noted, rivers and streams are channelized forms of run-off [Thornbury, 1978].

The drainage basin is described as a water catchment area that contributes run-off to the main stream [Knapp, 1979]. Wolf [1965] drew a distinction between artificial catchments and natural catchments. Artificial catchments are those urban areas, airfields and large road systems where man has covered greatly by paving and roofs, which carry rain directly to the drainage system. Natural catchments on the other hand include those areas where man has not changed the original land use and river channels.

Writing on the analysis of drainage networks, the "Blue Line" method, and involving interpretation of channel networks as portrayed on topographic maps was proposed [Harbor, 1994; Morisawa, 1957]. The "contour crenulations method" involves the insertion of streams where they are indicated by contour crenulations on maps [Drummond, 1974; Wien, 1980]. Drummond [1974] also showed that a U.S.A agency, Environmental Quality Laboratory (EQL) used the method successfully with supplement from air photographs and field surveys.

Furthermore, the U.S Open University 2nd Level Course Team [1972] proposed a morphometric analysis involving four main steps. The first step is called "order designation" which involves tracing out the drainage divide and the channels and then - designating the channels according to order. The next step is "order analysis" and this is done by measuring the length of such channel according to order. This is followed by counting the total number in each order and checking the total length of each. This may then be plotted on a semi-logarithmic paper.

The first detailed analysis of drainage network was qualitative [Schumm, 1977]. Also, it was shown that evolutionary process of drainage network can be studied experimentally [Parker, 1976].

In another study of "urban flood plain", data from a storm water monitoring programme to 
form a sub-catchment in terms of mass per unit area of run-off was used. Statistical analysis of all storms in the study yielded a fairly linear relationship between runoff volume and sediment load.

\section{THE STUDY AREA}

Calabar is the capital city of Cross River State; located at the extreme end of south-eastern Nigeria; between latitudes $5^{\circ} 55^{\prime} \mathrm{N}$ and $5^{\circ} 59^{\prime} \mathrm{N}$ and longitudes $8^{\circ} 15^{\prime} \mathrm{E}$ and $8^{\circ} 22^{\prime} \mathrm{E}$. The town is flanked on its eastern and western borders by two large rivers: the Great Qua River and Calabar River respectively (Figure 1). The area is part of the larger Cross River Basin which is drained by left bank tributaries of the River cross. It has a slight southward slope, and a definite sudden descent towards both the Qua and Calabar rivers. The highest north-point of built-up area reaches about $70 \mathrm{~m}$ above sea level.

As a coastal town, Calabar has a high relative humidity, usually between $80 \%$ and $100 \%$, resulting in high precipitation. Precipitation is characterized by a double- maxima rainfall which starts from April and ends in October reaching its Peak in June and September (Figure 2). It has been observed that climate and lithological base act to shape the topographic characteristics and output of a drainage basin [Wien, 1972].

\section{MATERIALS AND METHOD}

The procedures adopted for this study were two methods alongside field operations (15 - 18). The methods are the "Blue line" and "Contour

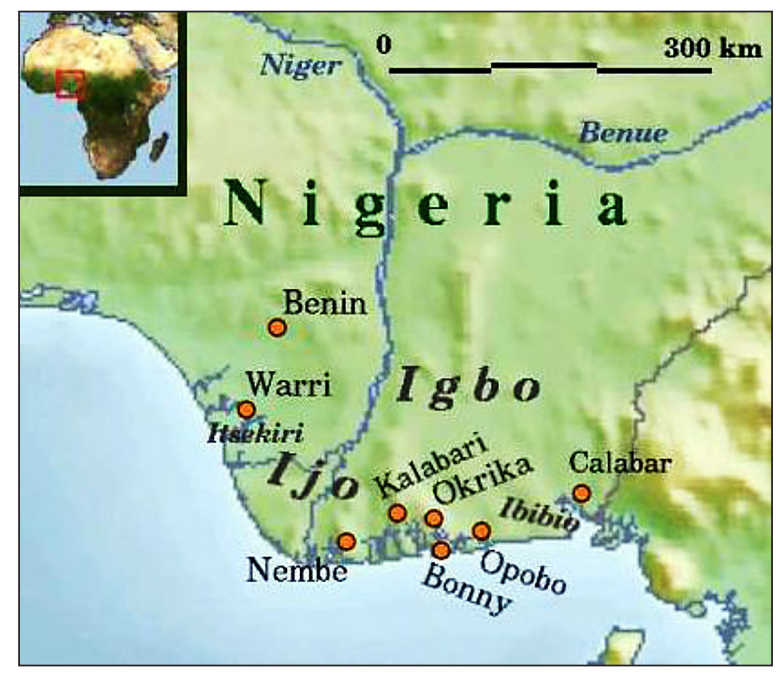

Figure 1. Location of Calabar crenulation" methods. An accurate topographic map of Calabar metropolis, drawn on a scale of 1:200 and contour interval of 50m was obtained from the State Ministry of Works and Housing. Due to the generally low-lying nature of the city's topography, the contour interval of $50 \mathrm{~m}$ was considered too high to give any meaningful topographic image for the purpose of detailed analysis.

As a result, the interpolation method was used to reduce the contour interval to $10 \mathrm{~m}$ (Figure 3). This involved tracing out four additional contour lines between two existing ones, maintaining their shapes, but differing their sizes in order to differentiate between significant and minor contours. An outlay of drainage networks was produced by inserting a flow line each at the "crenulations" or indentation of at least three contour lines. From the outlay it was possible to sub-divide the entire area into a system of contributing basins and subbasins. Such an approach was used in the analysis of the drainage development of the basin of the upper Trent, U.S.A. [Knapp, 1979].

\section{RESULTS AND DISCUSSION}

The Calabar drainage areas consist of two main watersheds trending north to south: the western one parallel to the Calabar River which lies on the left flank of the river; and the eastern

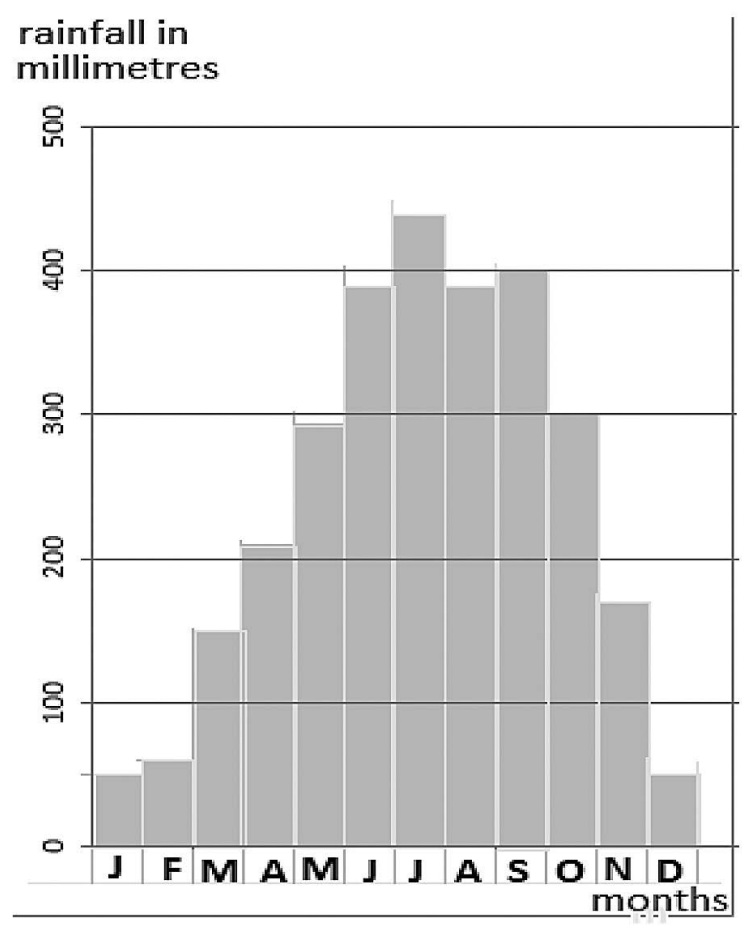

Figure 2. Average monthly rainfall figures for Calabar 


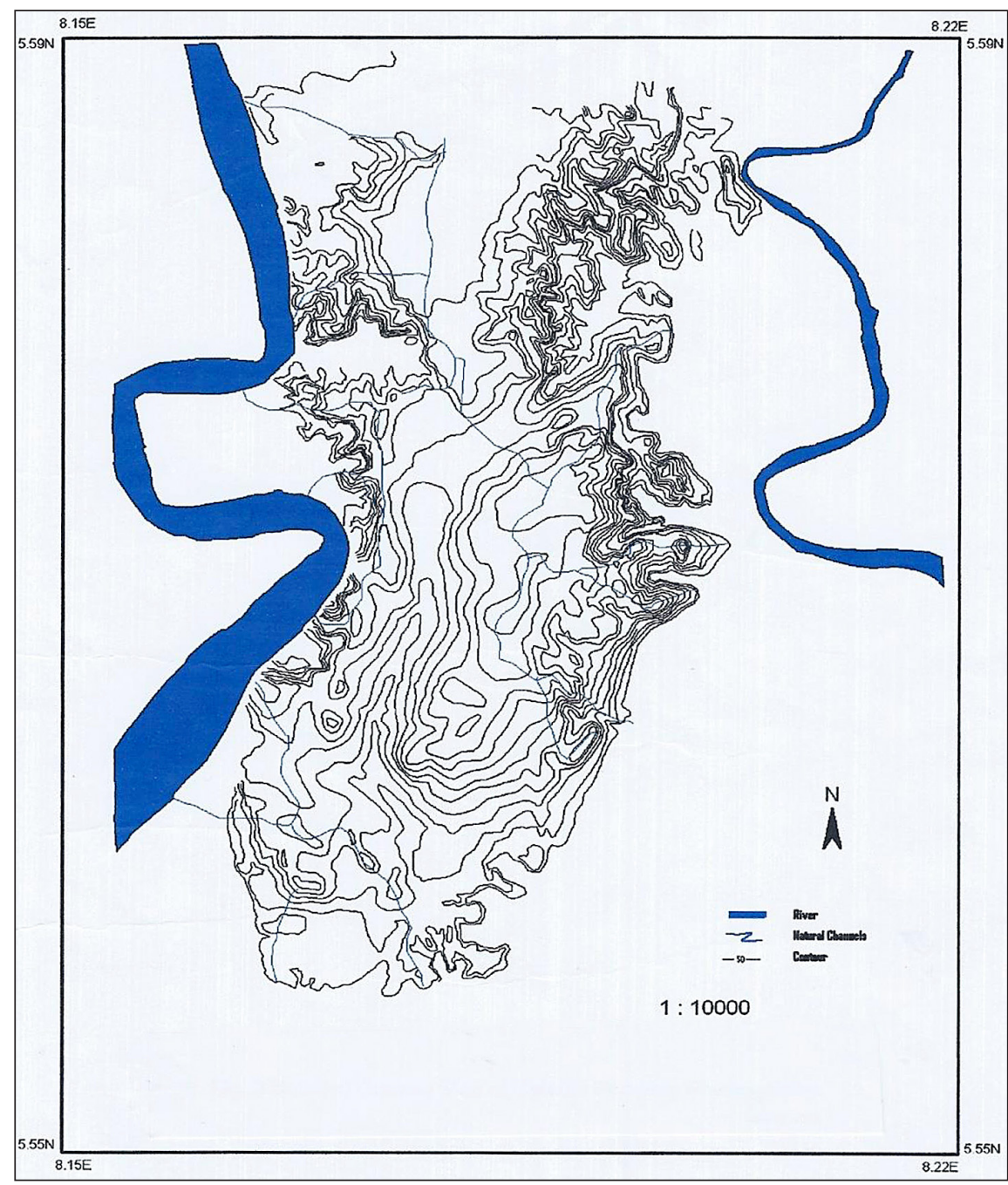

Figure 3. Detailed contour map of Calabar showing physiography

one along the Great Qua River. Within the two watersheds, five drainage basins were identified, namely, the western, northwestern, eastern, southeastern and the central basins.

The eastern and western basins were indicated by the slope which drains directly into the two rivers, while the central larger basin was defined by two converging slopes whose natural drainage discharges downstream into the Qua River. This Central basin was where the most devastating flood problems were recorded. Indeed, it was the total volume of run-off over this basin that had rendered a substantial portion of the Cross River University of Technology (CRUTECH) main campus staff quarters uninhabitable as a result of flood.

However, a sixth basin is recognized at the north point of these five basins, but its flows are directed in an opposite (i.e. South-North) direction (Figure 4).

All the five basins are made up of sub-basins and their networks. For ease of analysis, each ba- sin so delineated is numerically coded and the sub basins identified by alphabets (Figure 5).

Basin 1 corresponds to the central basin defined by the deep crenulation of contours of the central zone in a south-north direction. The main channel here passes through the central topographic trough in the city Centre, which runs southwards and empties into the Great Qua River. It receives almost all the surface flows from the other four basins, and thus corresponds to the 3rd order and highest segment of the entire basin area.

Basin 2 trends in a north-westerly direction and collects flows from the outer and northpoint limits of basin 1 and is expected to have discharged run-off into the Calabar River to the west. But due to urban development, run-off is converged mid-way in the basin centre and diverted into the main channel in basin 1 .

Basin 4 stretched from the $150^{\text {th }}$ contour at the southwestern flank, beginning at the crenulation between the two top slopes of Henshaw town and 


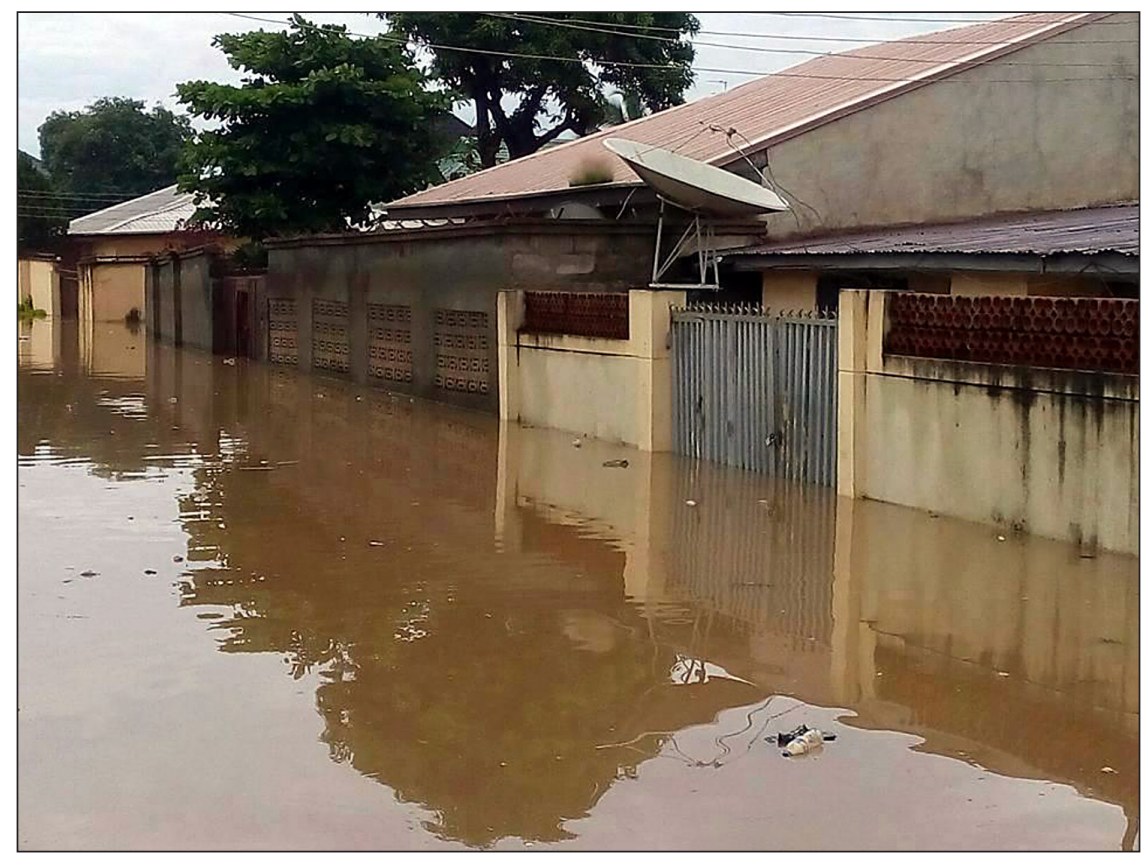

Figure 4. Flooding of neighborhoods in Calabar South

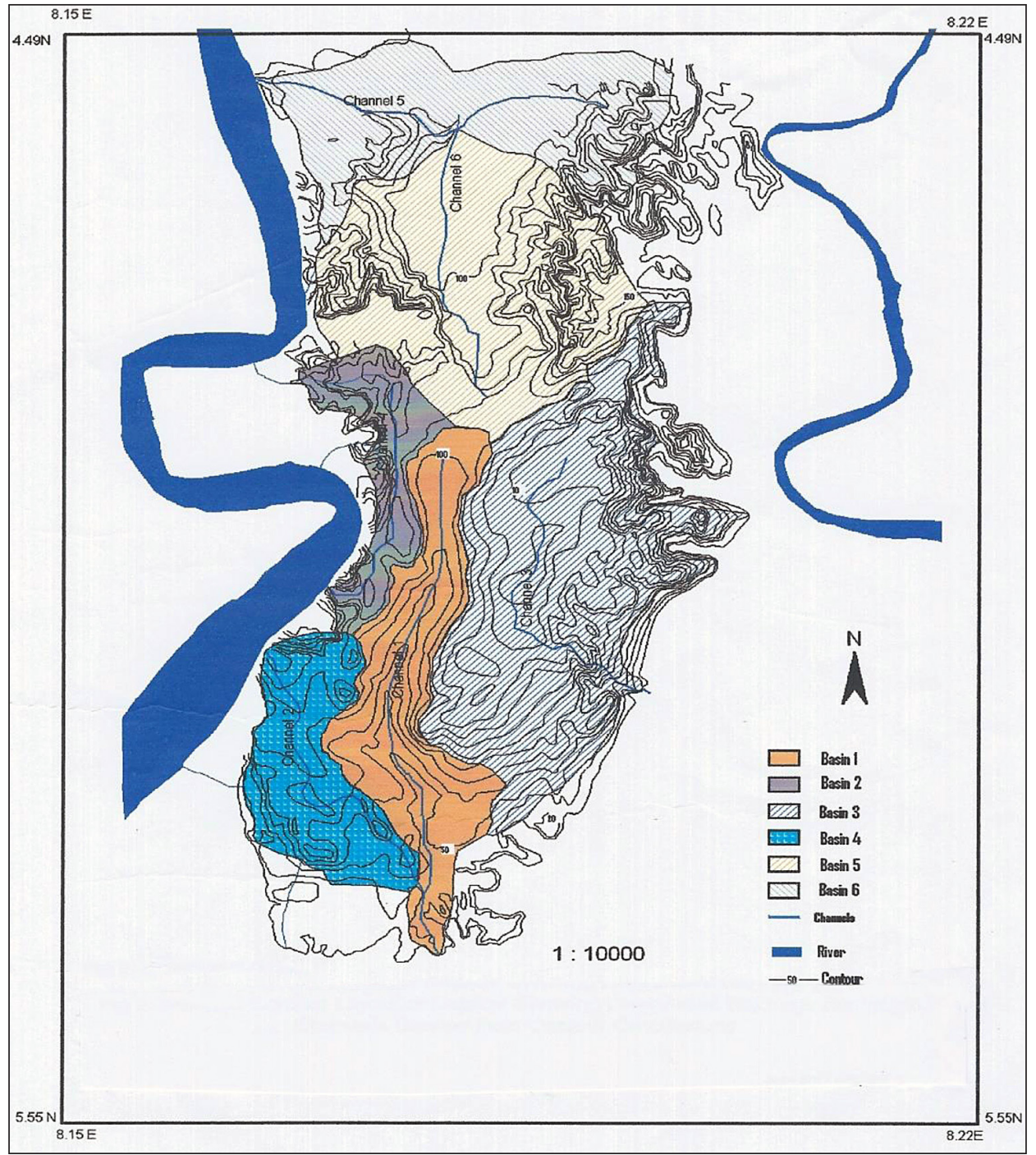

Figure 5. Detailed contour layout of Calabar showing designated drainage basins and channels derived from contour crenulations 
the Mbukpa area. It trends southeast ward and joins basin 1 at the lower- most segment.

Unfortunately, urban development has pushed flow upward causing run-off to be discharged into the trunk channel at the Mayne-Avenue/Atu street stretch. The basin covers a better part of south western Calabar. The stretch enclosed by the Hill top area of "Sacramento" and the old Parliamentary village, a central trough at Effio-Etta junction constitute basin 5 . The direction of run-off under natural conditions is supposed to be eastwards coinciding with the sixth basin at the northeast point. But urban road network has caused a diversion of flow into the Marian road extension segment, which tends to carry the flow into basin 2 through the lower segment of MCC road. But due to loss of gradient and massive sediment yield, a disruption is experienced thereby leading to pounding at the Effio-Ette round-about.

Basin 6 represents the northern limits of ba$\sin 2$ and 5. Its run-off flows are directed from the Ikot Ishie-Hill-crest, Northwards, towards Ikot Ansa axis. A distortion along the stretch has however, forced flows to be redirected through the Beebobsco area, cutting across the Murtala Muhammed Highway at that point. This accounts for the development of the conspicuous ravine along that portion of the highway, known as the Ikot Anwatim Ecological Disaster Zone, which had to be reclaimed through a Federal Government Contract.

At Ikot Anwatim the ecological problems arose following the completion of the Murtala Mohammed Highway in the 1970s. With this development imperviousness increased in the vi- cinity the area and (being the lowest point of the highway in this territory) large volumes of stormwaters were directed to this location from the north, south and east; resulting in flooding of the highway in the events of heavy rainfalls. Between the months of June and September, heavy rainfalls occur very often in Calabar (see Figure 2). By the early 1980's the floods had undermined the subbase of the highway, resulting in several lateral cracks across the highway in the vicinity of Ikot Anwatim. The need thus arose for the resolution of the problems of stormwater management in the vicinity of Ikot Anwatim on the Murtala Mohammed Highway.

The method that was adopted was a modified version of the classical system of stormwater management. The stormwater was collected from drain channels located on the eastern side of the highway, transported across the highway by means of underground channels and released (a few metres away from the western edge of the highway) into the shallow valley of Ikot Anwatim (see Figures 6, 7). It was probably hoped that the stormwaters would roll down harmlessly along the shallow valley, percolating gradually into the subsoil for the recharge of the underground aquifers. However, this did not happen. The situation that ensued in the end turned out to be completely contrary to all the expectations of the project developers - deep gully erosion (see Figures 7,8 ).

From the fore-going analysis, it can be seen that out of the six basins identified in the study area, four of them direct their runoff waters into the main channel of only one basin: First, this has obviously over-tasked the capacity of that chan-

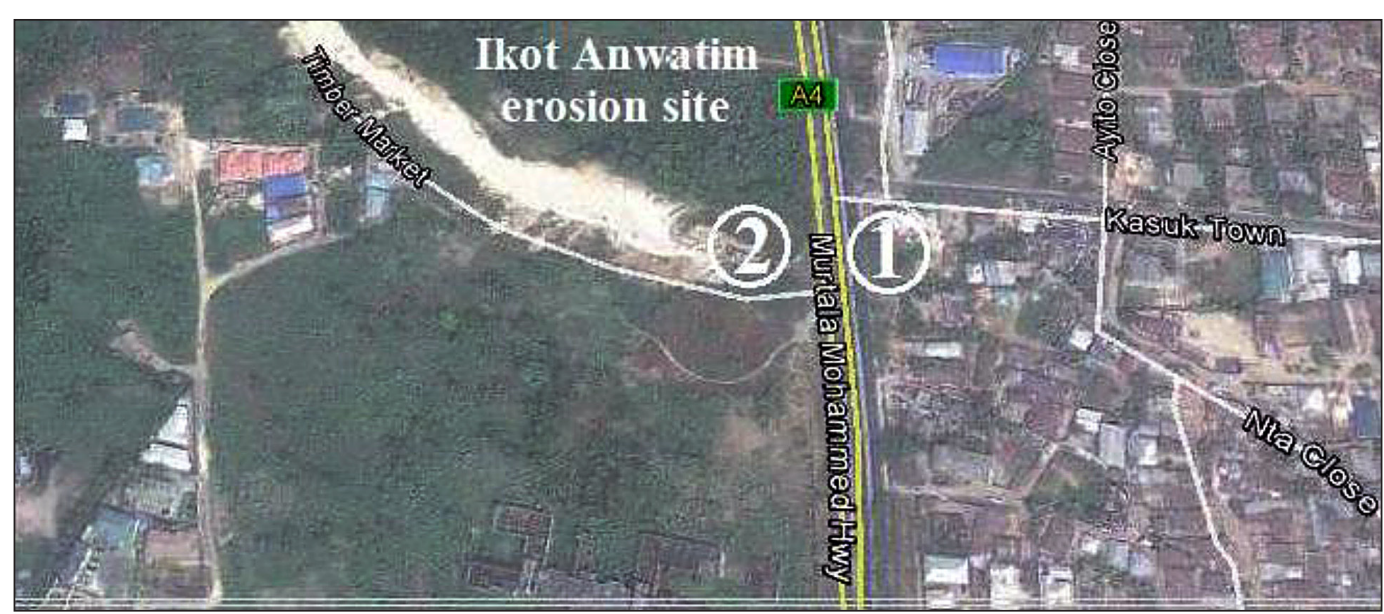

Figure 6. Ikot Anwantim ecological site (Source of map: Google Earth)

1 - point of collection of stormwaters on the eastern side of Murtala Mohammed Highway transportation westwards through channels buried under the highway; 2 - point of discharge of stormwaters into the valley at Ikot Anwatim on the western side Murtala Mohammed Highway 


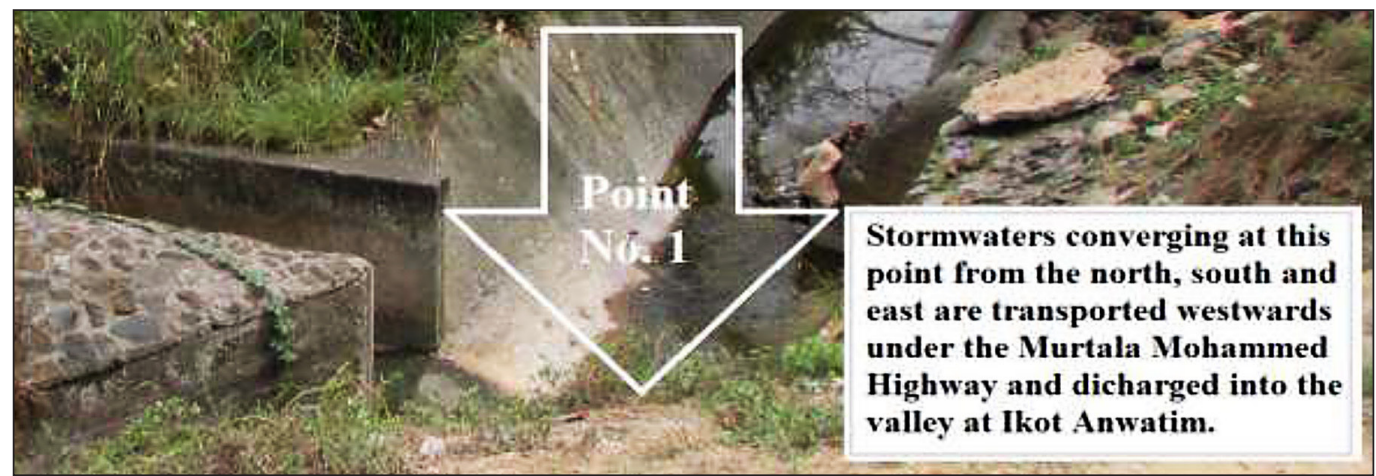

Figure 7. Stormwaters collected at this point are transported under the highway to Ikot Anwantim valley, where a very grave ecological disaster has developed

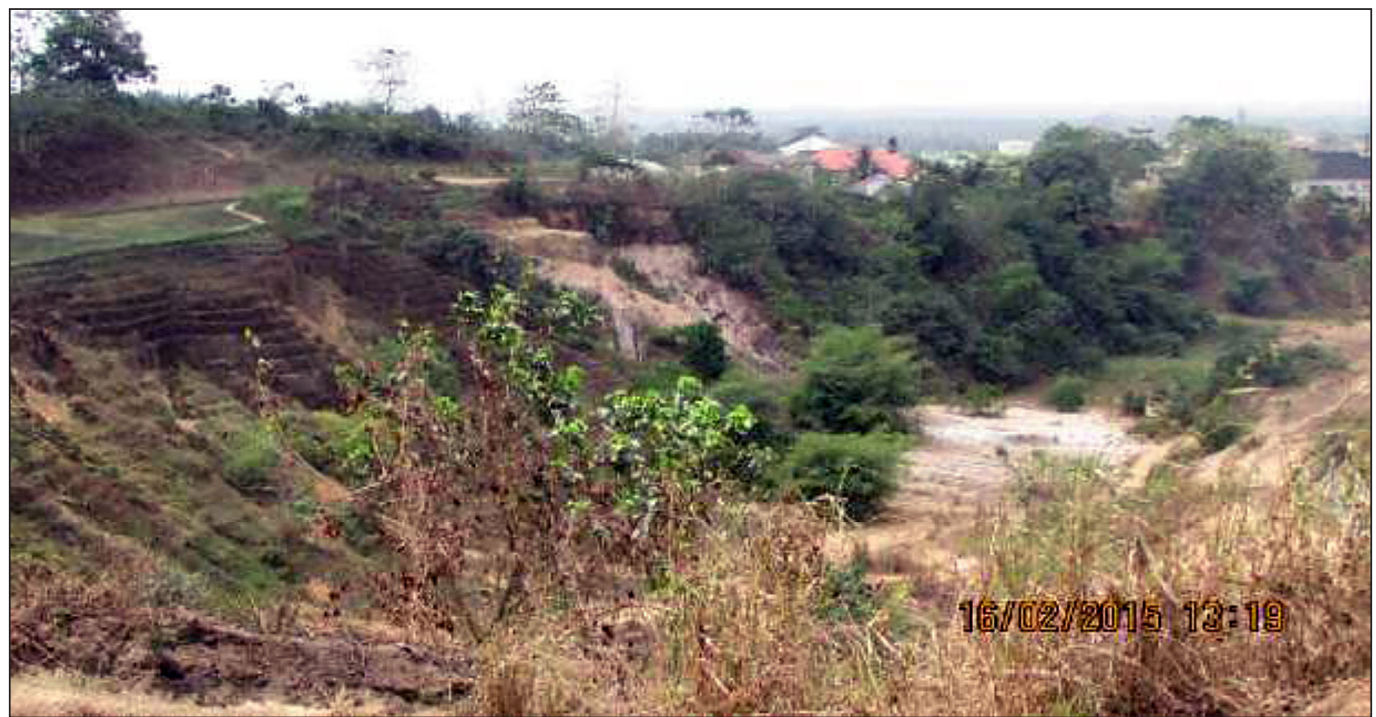

Figure 8. Ikot Anwantim: by reason of poor management of stormwaters, an ecologically productive land has been replaced by this barren valley

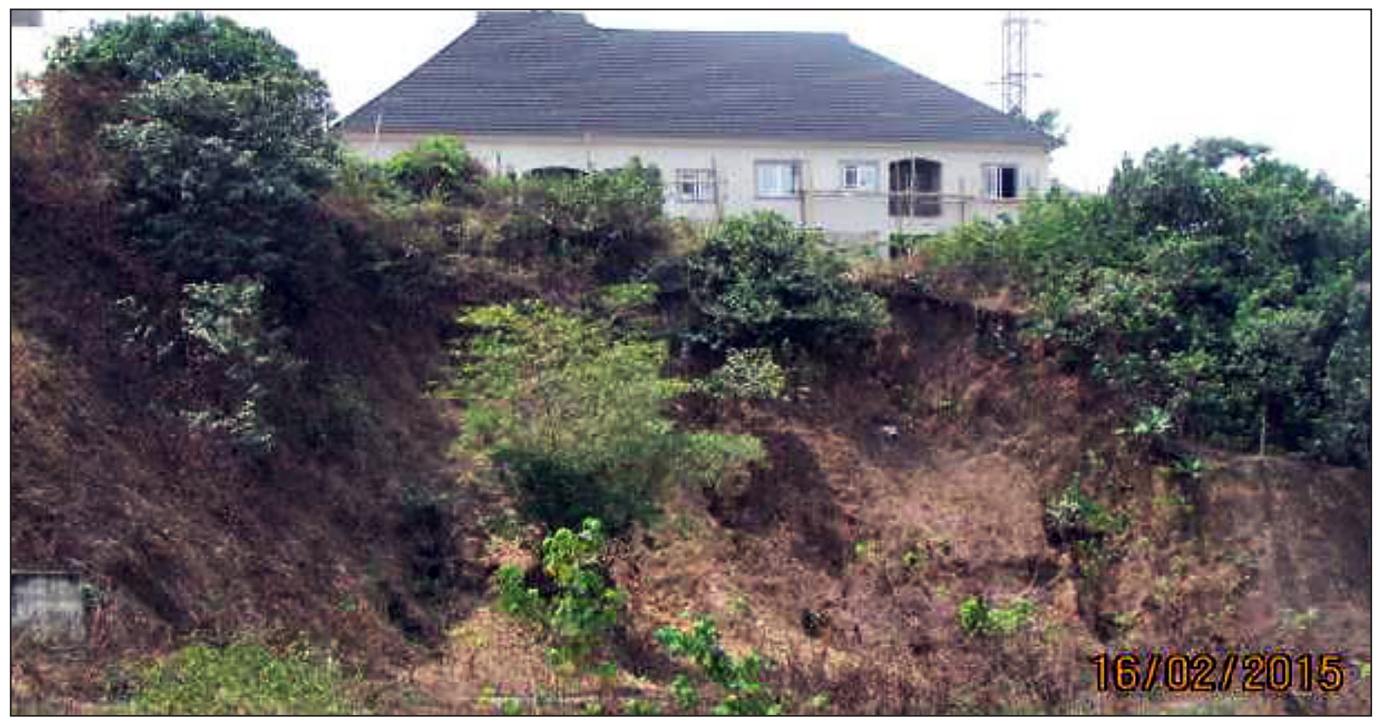

Figure 9. Ikot Anwantim: while erosion is constantly wearing away the sides of the valley, the risk of landslide is appreciated and new buildings are still springing up close to the edge of the precipice 
nel, thereby causing the intractable problems of flood and erosion in the down-stream segment of that channel. Secondly, the points of convergence of flows from these four basins with the trunk channel in basin 1 also coincide with the points of incidence of flash flood. Thirdly, the implication here is that floods are produced here not only by clogging of drains by refuse and sediments, but due largely to topographic alteration and changes in hydro-physical conditions due to urbanization.

\section{CONCLUSIONS}

This study employed cartographic techniques in examining the surface run-off characteristics of Calabar drainage area as a way of understanding the perennial problems of urban floods and erosion. The natural drainage network over the study area was reconstructed from prepared detailed topographic maps of the area.

The following conclusions were drawn from the analysis that followed:

1. That run-off channels in the Calabar drainage area radiates in a trellis manner similar to larger drainage basins, and thus could be studied in terms of the basic laws governing drainage basin morphometry.

2. That the existing drainage system in Calabar is not efficient, and serious run-off problems arise every year during the rainy season.

3. That drainage problems arise mainly because there are a total of six natural drainage basins in the area, taking their rise from two main watersheds which trend north to south within the township area. The basins are made up of subbasins, each with its specific drainage area.

Instead of a trunk channel for each basin to carry its run-off to the natural outlet direction, flow is diverted by urbanization into overlapping basins. Such locations are the points of incidence of flooding. Moreover, five out of the six basins converge their flows into one central channel, particularly at the down-stream segment. These features became apparent after the topographiccum-cartographic analysis.

It is thus recommended that for effective remediation of flood problems in Calabar metropolis, a system of six major drainage channels be designed and constructed for the entire Calabar area, each receiving run-off from its tributaries and from its basin area. This should be in conformity with the layout shown (Figure 5). There should also be an increasing downstream expansion of each channel size to cope with increasing flow volume with distance from basin head to outlet.

\section{REFERENCES}

1. Adeleye J.A. 1990. Effect of streamflow data record length on the accuracy of capacity estimates for direct supply reservoir. Water Resources: A Journal of the Nigerian Association of Hydrologists, L (2), 48-61.

2. Chima G.N. and Ugbong I.A. 2009. Characterizing surface runoff and urban floods in the Calabar Drainage Area. Journal of Science, Engineering and Technology, 16(2), 8829-8840.

3. Dobson N.O. 2006. NOAA coastal change analysis programme (C-CAP): Guidance for regional implementation. NOAA Technical Report, NMFS 123, New York.

4. Drummond F.X. 1974. Infiltration, its simulation for field conditions. In: Rodda J.C. (Ed.) Facets of Hydrology. John Wiley and Sons Co., New York.

5. Effiong-Fuller E.O. 1998. Environmental problems in Calabar urban: The hydrological perspective and the human dimension. In: Proceedings of the $41^{\text {st }}$ annual conference of the Nigeria Geographical Association, held at the University of Uyo, Akwa Ibom State, $31^{\text {st }}$ May $-4^{\text {th }}$ June.

6. Harbor M.J. 1994. A practical method for estimating the impact of land use change on surface runoff, ground water recharge and Wetland Hydrology. Journal of the American Planning Association, Jan 1.

7. Itam E.B., Ukorebi U.A., Yaro M.A., Ita E.E., Ugbong I.A., Ipia O.B., Ekeng P.O. 2015. Tracing ecological disasters through poor planning of infrastructure for housing development: The Ikot Nkebre episode in Calabar, Nigeria. The International Journal of Science and Technoledge, 3(8). 89-101.

8. Knapp J.B. 1979. Elements of geographical hydrology. George Allen and Co., London.

9. McCullagh P.S. 1978. Modern concepts in geomorphology. Oxford University Press, London.

10. Morisawa M.E. 1957. Quantitative geomorphology of some watersheds in the Appalachian Plateau. Bulletin of Geological Society of America, 23, 1025-1046.

11. Open University Science Course Team. 1972, The hydrology of lakes, Ohio.

12. Parker E.A. 1976. Models in flood plain management. Journal of Hydrology, 41.

13. Schumm S.A. 1977. The fluvial system. John Wiley and Sons Inc., New York. 
14. Shake J.C. 1970. Water and the city. In: Dewyter and Marcus (Ed.). Urbanization and Environment. George Allen and Co., London.

15. Schmitt T.G. 1997. Water - Protection - Human Beings. A triangular relation in changing times. Applied Geography and Development, 49.

16. Thornbury O.W. 1979. Principles of geomorphology. John Wiley and Sons Ltd., New York.

17. Ugbong I.A. 2001. A hydro-physical analysis of surface runoff: Channel characteristics and the incidence of flood and erosion over the Calabar drainage area, Nigeria. Unpublished M.Sc. thesis,
Department of Geography and Planning, University of Calabar, Calabar.

18. UNEP 1991. Urban drainage problems in developing countries. A publication of the United Nations Environmental Programme, Bangkok.

19. Wien B.B. 1980. Drainage density - an integrative measure of the dynamics and quality of watersheds. Annals of Geomorphology, Berlin.

20. Wolf P.O. 1965. Comparison of methods of flood estimation in river flood hydrology. In: Proceedings of the Symposium organized by the Institute of Civil Engineering, California. 